\title{
In-vitro antioxidant, anti-cancer, and anti- inflammatory activities of selected medicinal plants from western Nepal
}

Bishnu Prasad Pandey ${ }^{1 *} \mathbb{D}$, Kapil Adhikari ${ }^{1}$, Suman Prakash Pradhan ${ }^{1}$, Hee Jeong Shin ${ }^{2}$, Eun Kyeong Lee ${ }^{2}$ and Hye Jin Jung ${ }^{2,3^{*}}$

\begin{abstract}
Background: This study was focused on the measurement of anticancer properties of six medicinal plants from western Nepal in three cell lines; HeLa, Hep3B, and HCT116, and anti-inflammatory properties in RAW 264.7 cell line through $\mathrm{NO}_{1} \mathrm{PGE}_{2}$, and TNF-a production. In addition, the phytochemical screening, total phenolic, flavonoid content, and antioxidant properties were evaluated.

Results: The qualitative phytochemical analysis revealed the presence of different secondary metabolite and range of total phenolic and total flavonoid content. The highest antioxidant activities were observed in Bergenia pacumbis against both DPPH $\left(I C_{50}=25.97 \pm 0.19 \mu \mathrm{g} / \mathrm{mL}\right)$ and $A B T S\left(I C_{50}=14.49 \pm 0.40 \mu \mathrm{g} / \mathrm{mL}\right)$. Furthermore, the highest antiproliferative effect against cervical, liver, and colon cancer cell lines were observed in Melia azedarach as $I_{50}$ values of $10.50,5.30$, and $1.57 \mu \mathrm{g} / \mathrm{mL}$ respectively, while the strongest anti-metastatic potential on liver cancer cell line was found in Pleurospermum benthamii. In addition, P. benthamii showed the most potent anti-inflammatory effect in RAW264.7 murine macrophage cells.

Conclusion: This study provided the evidence for M. azedarach and P. benthamii to have great anticancer potential and finding builds the enough scientific backgrounds in future to isolate and purify the bioactive compounds for further applications.
\end{abstract}

Keywords: Medicinal plants, Anticancer, Anti-inflammatory, Antioxidant

\section{Background}

The use of plant-based medicines for the treatment of various ailments is practiced from ancient times such as Ayurveda, Unani, and Siddha, and has been part of human culture [1-3]. The knowledge of chemical constituents of plants is desirable for the discovery of therapeutic agents and scientific validation of folkloric remedies [4]. Further, plant-based medication are the basis of the modern pharmaceuticals and search for

\footnotetext{
* Correspondence: bishnu@ku.edu.np; poka96@sunmoon.ac.kr

'Department of Chemical Science and Engineering, Kathmandu University, P.O. Box 6250, Kavre, Dhulikhel, Nepal

${ }^{2}$ Department of Pharmaceutical Engineering \& Biotechnology, Sun Moon University, 70 Sunmoon-ro 221, Tangjeong-myeon, Asan-si, Chungnam 31460, Korea

Full list of author information is available at the end of the article
}

novel and functional extracts from medicinal plants are in central attraction in recent years because of the presence of diverse bioactive secondary metabolites such as alkaloids, terpenoids, glycosides, steroids, flavonoids, and phenolic compounds [5]. These bioactive molecules are reported to have several beneficial effects in lowering the risk of diseases caused by reactive oxygen species (ROS) [6] through different mechanisms of action such as scavenging free radicals, quenching ROS, inhibiting oxidative enzymes [7]. It is evident that plant extracts have diverse biochemical activities such as anti-allergic, antiinflammatory, antioxidant, anti-microbial, anti-fungal, antiviral, and anti-cancer $[7,8]$. The continuous screening of medicinal plants for their potential bioactivities is 
gaining attention in pharmaceutical, food industries, and cosmetics [9].

Cancer is a deadly disease which is proliferating rapidly and becomes one of the growing health problems worldwide due to the lack of widespread and comprehensive early detection methods and proper medicine [10-12]. Instead of significant development in biomedical science, cancer remains ambiguous especially from the therapeutic perspective and one of the greatest challenges to mankind [13, 14]. Further, it is one of the common causes of death contributing toward uncontrolled growth and invasion of the abnormal cells which leads to the formation of tumors in the human body [15, 16]. It is evident that natural products and bioactive compounds derived from medicinal plants and herbs have significant pharmacological activities and act as a cancer suppressant [17]. Different epidemiological and pharmacological studies suggested that the daily intake of certain phytochemicals can reduce the incidence of several types of cancer $[18,19]$. Furthermore, inflammation and oxidative stress have been reported to play an important role in the development of several diseases [20]. Although, anti-inflammatory agents such as nonsteroidal anti-inflammatory drugs (NSAID) are used for the treatment of inflammatory diseases, suffer from the side effect such as gastro-toxicity, hence it is an utmost need of development of safer anti-inflammatory agents [21].

Melia azedarach (Meliaceae) is commonly called as 'Bakaina'; traditionally used to cure skin disease, circulatory system disorder, fever, stomach problems, cuts, cough, aches, and dental problems [22] and have already proven antioxidant, antimicrobial, wound healing, hepatoprotective, anthelmintic, and antipyretic activities [23]. Asparagus racemosus (Asparagaceae) is commonly called as 'Kurilo'; traditionally used to cure stomach problems and skin diseases [24] and have antihepatotoxic, antineoplastic, antiprotozoal, adaptogenic, antiulcer, antioxidant, antilithiatic, antidepressant, anti-inflammatory, and cytotoxicity activities [25]. Thymus linearis (Lamiaceae) is commonly called as 'Ghodamarcha'; traditionally used to cure stomach problems, cough, cold, and eye infection [26] and have antihypertensive [27], anti-inflammatory, antipyretic [28], hepatoprotective [29], antioxidant, anticholinergic [30], and antimicrobial [31] activities. Pleurospermum benthamii (Apiaceae) is commonly called as 'Gandhaina' and used to cure Diarrhea, dysentery, constipation, gastritis, cough, cold, headache, and indigestion [2]. Bergenia pacumbis (Saxifragaceae) is commonly called as 'Pakhanved' and used to cure diarrhea, dysentery, vomiting, fever, cough, kidney problems, cold, urinary problems, and indigestion [32]. Murraya koenigii (Rutaceae) is commonly called as 'Kadipatta'; traditionally used to cure skin diseases, stomach problems, body aches, dental problem, and urinary tract infection [33] and have antimicrobial, antioxidant, anticancer, antiinflammatory, wound healing, hepatoprotective, antifungal, neuroprotective, and antidiabetic activities [34].

The western region of Nepal is rich in plant diversity of high medicinal values [35]. The increasing use of traditional practices for the treatment of diseases by herbal medicine demands more scientifically sound evidence for the ideologies behind therapies and for the effectiveness of plant-based medicines [36]. The six medicinal plants; $M$. azedarach, $A$. racemosus, $T$. linearis, $P$. benthamii, B. pacumbis, and M. koenigii from Karnali region of Nepal were selected based on their traditional medicinal uses and most used plant species for the invitro evaluation of biochemical activities. The main objectives of this study were to evaluate the total phenolic and flavonoid content; antioxidant properties; anticancer properties in three cell lines, HeLa, Hep3B, and HCT116; and anti-inflammatory properties in RAW 264.7 cell line through $\mathrm{NO}, \mathrm{PGE}_{2}$, and TNF- $\alpha$ production.

\section{Methods \\ Cell lines}

Colon carcinoma (HCT116), hepatocarcinoma (Hep3B), cervical carcinoma (HeLa), and RAW264.7 murine macrophage cell lines were obtained from Korean Cell Line Bank (KCLB).

\section{Plant collection, authorization, and extract preparation}

Plants were collected from the Humla and Mugu District of Karnali Province and Banke district of Province 5 of Nepal. The plant species were scientifically authorized in the National Herbarium and Plant Laboratory (KATH) Godawori, Lalitpur, Nepal (Table 1). The collected plant samples were dried at room temperature and made powdered by grinding in an electrical grinder. Ten-gram powder of each sample was macerated with $100 \mathrm{~mL}$ of absolute methanol (HPLC-grade) and kept overnight on a rotary shaker (JEIO TECH, South Korea) at $150 \mathrm{rpm}$ at $25{ }^{\circ} \mathrm{C}$ temperature. On the next day, the entire mixture was filtrated and concentrated to dryness by evaporating on a vacuum evaporator (hanil Modul 4080C, South Korea) as the slightly modified procedure of previous investigators [37]. The extracted crude samples were kept in airtight glass vials and stored at $4{ }^{\circ} \mathrm{C}$ until use.

\section{Qualitative phytochemical screening}

The qualitative phytochemical analysis of Alkaloids, Saponin, Quinone, Sterol, Cardiac glycoside, Tannin, Terpenoid, Protein, and Reducing sugar was performed as the procedure followed by the previous investigators [38-40]. 
Table 1 Detail on plants collection

\begin{tabular}{|c|c|c|c|c|}
\hline Plants (Family) & Plant code & Vernacular name & Collection site & Collected parts \\
\hline Melia azedarach L. (Meliaceae) & $\mathrm{T} 1$ & Bakaina & $28^{\circ} 12^{\prime} 12^{\prime \prime} \mathrm{N} 81^{\circ} 48^{\prime} 06^{\prime \prime} \mathrm{E}$ & Leaves \\
\hline Asparagus racemosus Willd. (Asparagaceae) & $\mathrm{T} 2$ & Ban Kurilo & $28^{\circ} 12^{\prime} 12^{\prime \prime} \mathrm{N} 81^{\circ} 48^{\prime} 06^{\prime \prime} \mathrm{E}$ & Rhizome \\
\hline Thymus linearis Benth. (Lamiaceae) & T3 & Ghodamarcha & $29^{\circ} 07^{\prime} 52^{\prime \prime} \mathrm{N} 82^{\circ} 30^{\prime} 50^{\prime \prime} \mathrm{E}$ & Leaves \\
\hline Pleurospermum benthamii (DC.) C.B. Clarke (Apiaceae) & $\mathrm{T} 4$ & Gandhaino & $29^{\circ} 38^{\prime} 38^{\prime \prime} \mathrm{N} 82^{\circ} 06^{\prime} 37^{\prime \prime} \mathrm{E}$ & Leaves \\
\hline Bergenia pacumbis (Buch. -Jam.ex D. Don) (Saxifragaceae) & T5 & Pakhanved & $29^{\circ} 07^{\prime} 52^{\prime \prime} \mathrm{N} 82^{\circ} 30^{\prime} 50^{\prime \prime} \mathrm{E}$ & Roots \\
\hline Murraya koenigii (L.) Spreng. (Rutaceae) & T6 & Kadipatta & $28^{\circ} 12^{\prime} 12^{\prime \prime} \mathrm{N} 81^{\circ} 48^{\prime} 06^{\prime \prime} \mathrm{E}$ & Leaves \\
\hline
\end{tabular}

\section{Determination of total flavonoid content}

Aluminum chloride $\left(\mathrm{AlCl}_{3}\right)$ colorimetric assay was performed for the determination of total flavonoid content (TFC) as the procedure described by previous investigators with slide modifications [41]. The absorbance of the reaction mixture was measured at $510 \mathrm{~nm}$ using a UVVisible spectrophotometer (Shimadzu UV-1800). In detail, $500 \mu \mathrm{L}$ plant extract of $1 \mathrm{mg} / \mathrm{mL}$ concentration was mixed with $2 \mathrm{~mL}$ of distilled water and $150 \mu \mathrm{L}$ of $5 \% \mathrm{NaNO}_{2}$. After 5 min of incubation at dark, $150 \mu \mathrm{L}$ of $10 \% \mathrm{AlCl}_{3}$ was added and incubated further for $6 \mathrm{~min}$. Then, $1 \mathrm{~mL}$ $\mathrm{NaOH}$ of $1 \mathrm{M}$ concentration and distilled water was added to maintain $5 \mathrm{~mL}$ reaction volume and absorbance was taken. TFC was quantified from the calibration curve $\left(R^{2}\right.$ $=0.990)$ with quercetin as a standard. The results were expressed as milligram of quercetin equivalents per gram of dry weight of extract (mg QE/g DW).

\section{Determination of total phenolic content}

Folin-Ciocalteu's technique was used to determine total phenolic content (TPC) as the procedure of previous investigators with slight modifications [42]. The absorbance was measured at $765 \mathrm{~nm}$ using a UV-Visible spectrophotometer. In detail, $500 \mu \mathrm{L}$ crude plant extract of $1 \mathrm{mg} / \mathrm{mL}$ concentration was mixed with $800 \mu \mathrm{L}$ distilled water and $100 \mu \mathrm{L}$ Folin-Ciocalteu's reagent. Then, $300 \mu \mathrm{L}$ of $7 \%$ $\mathrm{Na}_{2} \mathrm{CO}_{3}$ was added after 5 min of incubation at dark followed by another $30 \mathrm{~min}$ of incubation in dark and dilution of reaction mixture to $2 \mathrm{~mL}$ by addition of distil water. TPC was quantified from the calibration curve $\left(R^{2}\right.$ $=0.994$ ) with gallic acid as a standard. Results were expressed as milligram of gallic acid equivalent per gram dry weight of extract (mg GAE/g DW).

\section{In-vitro DPPH and ABTS assay for the determination of antioxidant activities}

Free radical scavenging was determined by 1,1-diphenyl 1-2-picryl-hydrazyl (DPPH) assay [43]. For the measurement of antioxidant activity, $1 \mathrm{~mL}$ of plant extracts $(10$, $20,40,60,80,100 \mu \mathrm{g} / \mathrm{mL}$ ) was mixed with $3 \mathrm{~mL}$ of the $\mathrm{DPPH}$ solution of $100 \mathrm{mM}$ concentration. The reaction mixtures were incubated for $30 \mathrm{~min}$ in dark and absorbance was recorded at $517 \mathrm{~nm}$ using a UV-visible spectrophotometer. An equal volume of methanolic DPPH in the place of the sample was used as a positive control and gallic acid as a standard.

In addition, the 2,2'-azino-bis (3-ethylbenzothiazoline6-sulphonic acid) (ABTS) cation decolorization assay was also performed for the evaluation of antioxidant potential of the plant extracts by using standard procedures followed by the previous investigators slight modifications [44]. An aliquot of $1 \mathrm{~mL}$ of plant extract $(10,20$, $40,60,80,100 \mu \mathrm{g} / \mathrm{mL}$ ) was mixed with $3 \mathrm{~mL}$ of ABTS working solution and incubated for $10 \mathrm{~min}$ in dark. The absorbance was taken at $734 \mathrm{~nm}$. The $50 \%$ methanolic ABTS in the place of plant extract was used as a positive control and gallic acid as a standard.

The percentage of DPPH and ABTS scavenging was calculated by the following formula.

$$
\begin{aligned}
& \% \text { Radical scavenging } \\
& \qquad=\frac{\text { Absorbance of control - Absorbance of test }}{\text { Absorbance of control }} * 100 \%
\end{aligned}
$$

\section{Anticancer activities \\ Cell culture and growth assay}

The anticancer activities of the plant extract were measured in three different cell lines HCT116 (colon carcinoma), Hep3B (hepatocarcinoma), and HeLa (cervical carcinoma). HCT116 colon carcinoma cells were grown in RPMI 1640 medium containing 10\% fetal bovine serum (FBS). Whereas, Hep3B hepatocarcinoma and HeLa cervical carcinoma cells were grown in Dulbecco's modified Eagle medium (DMEM) supplemented with $10 \% \mathrm{FBS}$ and grown at $37{ }^{\circ} \mathrm{C}$ in a humidified $5 \% \mathrm{CO}_{2}$ incubator. For cell growth assay, cells seeded at $2 \times$ $10^{3}$ cells/well into 96-well culture plates (SPL Lifesciences, Gyeonggi, Korea) were treated with each plant extract at various concentrations (3.12, 6.25, $12.5,25,50,100,200 \mu \mathrm{g} / \mathrm{mL}$ ) for $72 \mathrm{~h}$. Cell growth was measured using the 3-(4,5-dimethylthiazol-2-yl)-2, 5-diphenyl tetrazolium bromide (MTT) colorimetric assay [45]. The absorbance of each well was determined at a wavelength of $540 \mathrm{~nm}$ using a microplate reader (Thermo Fisher Scientific, Finland). 


\section{Wound healing assay}

Cell migration was analyzed using a wound healing assay in the Hep3B cell line by using the standard protocol [46]. Briefly, cells were seeded into 24-well plates and grown to $90 \%$ confluence. The confluent monolayer cells were scratched using the $10 \mu \mathrm{L}$ of a sterile pipette tip and washed using PBS buffer to remove the nonadherent cells in each well. The cells were treated with the plant extract at different concentrations ( 25 and 50 $\mu \mathrm{g} / \mathrm{mL}$ ) and control cells were untreated with plant extract. The cells were further grown up to $48 \mathrm{~h}$ and the perimeter of the central cell free zone was imaged with an optical microscope (Olympus, USA).

\section{Anti-inflammatory activities}

\section{Cell culture and cytotoxicity assay}

The anti-inflammatory activities of the plant extract were measured in RAW264.7 murine macrophage cells [47]. The cells were grown in DMEM medium supplemented with $10 \%$ FBS and maintained at $37{ }^{\circ} \mathrm{C}$ in a humidified $5 \% \mathrm{CO}_{2}$ incubator. The RAW264.7 cells $(5 \times$ $10^{3}$ cells/well) were seeded into 96-well culture plate with various concentrations of the plant extracts $(0.39$, $0.78,1.56,3.12,6.25,12.5 \mu \mathrm{g} / \mathrm{mL}$ ) and incubated for 24 $\mathrm{h}$. The cell viability was measured by the addition of 10 $\mu \mathrm{L}$ of WST-1 reagents to each well, and the cells were incubated for $2 \mathrm{~h}$. The absorbance of each well was determined at a wavelength of $450 \mathrm{~nm}$ using a microplate reader.

\section{Measurement of NO production}

The NO production was determined by using Griess reagent [48]. Briefly, the RAW264.7 cells $\left(5 \times 10^{3}\right.$ cells/ well) were treated with the plant extracts $(1,2.5,5,10$, $20 \mu \mathrm{g} / \mathrm{mL}$ ) for $1 \mathrm{~h}$, followed by incubation with $1 \mu \mathrm{g} / \mathrm{mL}$ LPS for another $24 \mathrm{~h}$. Briefly, conditioned medium (50 $\mu \mathrm{L})$ was mixed with the same volume of Griess reagent (1\% sulfanilamide in 5\% phosphoric acid and $0.1 \%$ naphthyl ethylenediamine dihydrochloride) and then incubated at room temperature for $5 \mathrm{~min}$. The amount of $\mathrm{NO}$ production was determined at $540 \mathrm{~nm}$ using a microplate reader.

\section{Measurement of $\mathrm{PGE}_{2}$ and TNF- $a$ by enzyme-linked immunosorbent assay}

Briefly, RAW264.7 cells were treated with the plant extract $(1,2.5,5,10 \mu \mathrm{g} / \mathrm{mL})$ for $1 \mathrm{~h}$ and followed by incubation with $1 \mu \mathrm{g} / \mathrm{mL}$ LPS for $24 \mathrm{~h}$. The supernatant was used to determine the production of $\mathrm{PGE}_{2}$, TNF- $\alpha$ in RAW264.7 cells using the enzyme-linked immunosorbent assay (ELISA) kits (R\&D Systems, Minneapolis, MN, USA) according to the manufacturer's instructions as by previous investigators [49].

\section{Statistical tools}

All the analyses were performed in triplicate for TFC, TPC, antioxidant, anticancer, and anti-inflammatory activities, and the results were expressed as mean value \pm standard deviation. The $\mathrm{IC}_{50}$ values for antioxidant activities were calculated by using a radical scavenging percentage in Microsoft Excel 2013. In the wound healing, $\mathrm{NO}, \mathrm{PGE}_{2}$, and TNF- $\alpha$ assays, statistical analysis was analyzed using the analysis of variance (one-way ANOVA) with SPSS statistics package (SPSS 9.0; SPSS Inc.). Post hoc analysis was carried out by Tukey's test. A $p$ value of $<0.05$ was considered a statistically significant difference.

\section{Results \\ Phytochemicals, total flavonoid content, and total} phenolic content

The results on qualitative phytochemicals analysis revealed the presence of diverse secondary metabolites namely alkaloids, saponin, quinone, sterol, cardiac glycoside, tannin, terpenoid, protein, and reducing sugar in most of the plant extracts (Table 2). Among all, alkaloids, cardiac glycoside, and terpenoid were highly detected phytochemicals, whereas saponin was the least. The extract of $B$. pacumbis, T. linearis, and A. racemosus showed high phytochemicals content while least by $M$. azedarach.

The results obtained from a preliminary analysis of total flavonoid content (TFC) and total phenolic content (TPC) were summarized in Table 3. The highest TFC was found in B. pacumbis (145.70 $\pm 0.38 \mathrm{mg} \mathrm{QE} / \mathrm{g} \mathrm{DW})$ followed by $M$. koenigii $(102.68 \pm 1.38 \mathrm{mg}$ QE/g DW)

Table 2 Results on qualitative phytochemical screening

\begin{tabular}{|c|c|c|c|c|c|c|c|c|c|}
\hline Plants & Alkaloids & Saponin & Quinone & Sterol & Cardiac glycoside & Tannin & Terpenoid & Protein & Reducing sugar \\
\hline M. azedarach & + & - & - & - & + & - & + & - & - \\
\hline A. racemosus & + & + & + & + & + & - & + & + & + \\
\hline T. linearis & + & - & + & + & + & + & + & + & + \\
\hline P. benthamii & + & - & + & + & + & - & + & + & - \\
\hline B. pacumbis & + & - & + & + & + & + & + & + & + \\
\hline M. koenigii & + & - & - & + & + & + & + & - & + \\
\hline
\end{tabular}

-; Not detected, +; Detected 
Table 3 Results on total flavonoid content and total phenolic content

\begin{tabular}{lll}
\hline Plants & $\begin{array}{l}\text { Total flavonoid content } \\
\text { (mg QE/g DW) }\end{array}$ & $\begin{array}{l}\text { Total phenolic content } \\
\text { (mg GAE/g DW) }\end{array}$ \\
\hline M. azedarach & $20.31 \pm 0.83$ & $96.02 \pm 0.89$ \\
A. racemosus & $3.61 \pm 0.59$ & $12.55 \pm 0.60$ \\
T. linearis & $61.22 \pm 0.06$ & $78.20 \pm 1.32$ \\
P. benthamii & $6.86 \pm 0.77$ & $11.38 \pm 0.94$ \\
B. pacumbis & $145.70 \pm 0.38$ & $208.39 \pm 0.65$ \\
M. koenigii & $102.68 \pm 1.38$ & $178.04 \pm 1.12$ \\
\hline
\end{tabular}

and T. linearis $(61.22 \pm 0.06 \mathrm{mg} \mathrm{QE} / \mathrm{g} \mathrm{DW})$. Whereas, least TFC was observed in A. racemosus $(3.61 \pm 0.59 \mathrm{mg}$ QE/g DW). Similarly, the highest TPC was found in $B$. pacumbis (208.39 $\pm 0.65 \mathrm{mg}$ GAE/g DW) followed by M. koenigii $(178.04 \pm 1.12 \mathrm{mg} \mathrm{GAE} / \mathrm{g} \mathrm{DW})$ and M. azedarach (96.02 $\pm 0.89 \mathrm{mg} \mathrm{GAE} / \mathrm{g} \mathrm{DW})$. The least phenolic content was observed in A. racemosus (12.55 \pm 0.60 $\mathrm{mg}$ GAE/g DW) and P. benthamii (11.38 $\pm 0.94 \mathrm{mg}$ GAE/g DW).

\section{Antioxidant activities}

The overall results on $\mathrm{IC}_{50}$ values for $\mathrm{DPPH}$ assay and ABTS assay were determined on the basis of radical scavenging percentage and are shown in Table 4. Our results revealed the highest antioxidant activities in $B$. pacumbis against both $\mathrm{DPPH}\left(\mathrm{IC}_{50}=25.97 \pm 0.19 \mu \mathrm{g} /\right.$ $\mathrm{mL})$ and $\mathrm{ABTS}\left(\mathrm{IC}_{50}=14.49 \pm 0.40 \mu \mathrm{g} / \mathrm{mL}\right)$ followed by T. linearis against $\mathrm{DPPH}\left(\mathrm{IC}_{50}=142.59 \pm 2.60 \mu \mathrm{g} / \mathrm{mL}\right)$ and ABTS $\left(\mathrm{IC}_{50}=64.92 \pm 1.68 \mu \mathrm{g} / \mathrm{mL}\right)$ and least was found in $A$. racemosus against both $\mathrm{DPPH} \quad\left(\mathrm{IC}_{50}=\right.$ $873.80 \pm 49.10 \mu \mathrm{g} / \mathrm{mL})$ and $\mathrm{ABTS}\left(\mathrm{IC}_{50}=502.72 \pm 9.80\right.$ $\mu \mathrm{g} / \mathrm{mL}$ ). The percentage of radical scavenging of plant extracts was shown in Fig. 1.

\section{Anticancer activities}

To evaluate the anticancer activities of the plant extracts, we examined the anti-proliferative effect of plant extract against HeLa, Hep3B, and HCT116 cancer cell lines. Analyzed plant extracts revealed a dose-dependent antiproliferative effect. The cancer cells were cultured for 72 $\mathrm{h}$ in the presence of each plant extract at various concentrations, and then viable cells were measured by MTT assay. Among six extracts tested, M. azedarach most effectively inhibited the growth of HeLa, Hep3B, and HCT116 cancer cells, with $\mathrm{IC}_{50}$ values of 10.50 , 5.30 , and $1.57 \mu \mathrm{g} / \mathrm{mL}$, respectively (Fig. 2). Followed by $M$. koenigii and $P$. benthamii extract with $\mathrm{IC}_{50}$ value of $43.82,31.38$, and 42.73 and $42.00,81.15$, and $31.63 \mu \mathrm{g} /$ mL respectively toward HeLa, Hep3B, and HCT116 cell line (Table 4).

In order to evaluate the effectiveness of the plant extracts on metastasis of cancer cells, it was analyzed using the wound healing assay against Hep3B cell line. Antimetastatic effect of the plant extract against the Hep3B was analyzed and the percentage migration was recorded at $24 \mathrm{~h}$ and $48 \mathrm{~h}$ of incubation. Results revealed that plant extract has tendencies to suppress the migration of the cell. The inhibitory effects of the plant extracts on the Hep3B liver cancer cell migration were evaluated. The result showed that the wound scratch in untreated control cells was fully closed after $48 \mathrm{~h}$ of incubation, whereas treatment with plant extracts suppressed effect on the migration of Hep3B cells (Fig. 3a, b).

\section{Anti-inflammatory activities}

To determine the effects of the plant extracts on RAW264.7 macrophage cell viability, the WST-1 assay was performed at $24 \mathrm{~h}$ after treatment with the indicated concentrations of the plant extracts. Five other plant extracts, except $M$. azedarach, did not cause any significant cytotoxicity up to $12.5 \mu \mathrm{g} / \mathrm{mL}$ in RAW264.7 cells (Fig. 4a, b). Furthermore, to evaluate the effects of the plant extracts on production of nitric oxide (NO), a principal pro-inflammatory mediator, RAW264.7 cells were pretreated with the plant extracts for $1 \mathrm{~h}$ and then stimulated with lipopolysaccharide (LPS) for $24 \mathrm{~h}$. Our results revealed that the extract of $P$. benthamii shows the significant inhibition in LPS-induced NO production as compared with other LPS-treated plant extracts with no cytotoxicity. To our knowledge, this is the first report of the inflammatory activities of the $P$. benthamii. In order to further confirm the anti-inflammatory activities

Table 4 Results on antioxidant and anticancer activities

\begin{tabular}{|c|c|c|c|c|c|}
\hline \multirow[t]{2}{*}{ Plants } & \multicolumn{2}{|c|}{$\mathrm{IC}_{50}$ values for antioxidant activities $(\mu \mathrm{g} / \mathrm{mL})$} & \multicolumn{3}{|c|}{$\mathrm{IC}_{50}$ values for antiproliferative activities $(\mu \mathrm{g} / \mathrm{mL})$} \\
\hline & DPPH & ABTS & HeLa & Нер3В & HCT116 \\
\hline M. azedarach & $424.62 \pm 12.22$ & $151.57 \pm 1.22$ & $10.50 \pm 1.50$ & $5.30 \pm 1.36$ & $1.57 \pm 1.33$ \\
\hline A. racemosus & $873.80 \pm 49.10$ & $502.72 \pm 9.80$ & $>200.00 \pm 1.16$ & $136.2 \pm 1.06$ & $133.20 \pm 1.06$ \\
\hline T. linearis & $142.59 \pm 2.60$ & $64.92 \pm 1.68$ & $162.3 \pm 1.03$ & $81.56 \pm 1.11$ & $113.60 \pm 2.17$ \\
\hline P. benthamii & $173.30 \pm 2.69$ & $122.39 \pm 0.84$ & $42.71 \pm 1.60$ & $81.15 \pm 1.11$ & $31.63 \pm 1.15$ \\
\hline B. pacumbis & $25.97 \pm 0.19$ & $14.49 \pm 0.40$ & $49.00 \pm 1.10$ & $157.1 \pm 1.33$ & $>200.00 \pm 1.49$ \\
\hline M. koenigii & $194.65 \pm 4.41$ & $58.74 \pm 0.32$ & $43.82 \pm 1.09$ & $31.38 \pm 1.22$ & $42.73 \pm 1.06$ \\
\hline
\end{tabular}




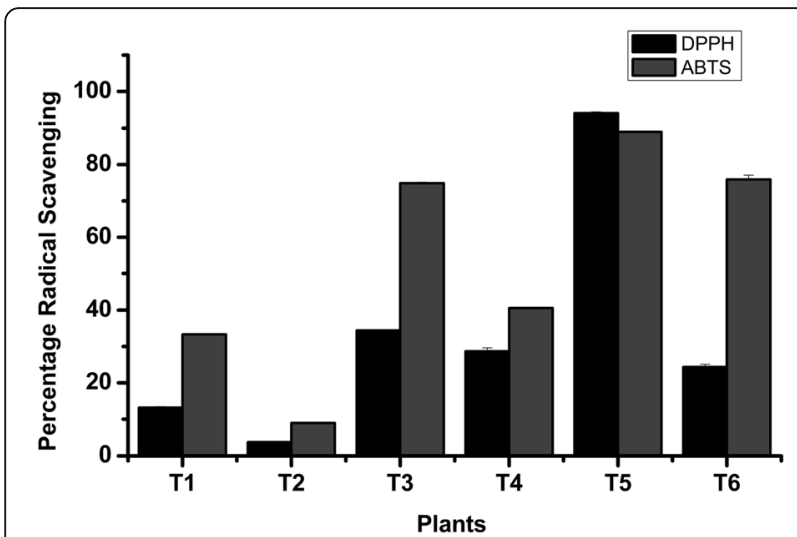

Fig. 1 Percentage radical scavenging of DPPH and ABTS at $100 \mu \mathrm{g} /$ $\mathrm{mL}$ plant extracts concentration.

of the P. benthamii methanol extract, we next evaluated the other pro-inflammatory cytokines $\mathrm{PGE}_{2}$ and TNF- $\alpha$ in the culture supernatant that were determined by ELIS A. Our results revealed that $P$. benthamii methanol extract reduced the LPS-induced expression of the $\mathrm{PGE}_{2}$ and TNF- $\alpha$ in dose-dependent manner (Fig. 4c, d).

\section{Discussion}

In developing countries, around $70-80 \%$ of the population relies on medicinal herbs and plants as primary health care [50]. Although modern drugs are accessible and effective in curing many diseases, herbal remedies are gaining popularity day by day owing to its fewer side effects and toxicity [51]. In our present study, we evaluated the medicinal plant extract collected from the Western region of Nepal for their potential health benefits such as antioxidant, anti-cancer, and anti-inflammatory activities. Crude methanol extract revealed the presence of diverse phytonutrients such as steroids, flavonoids, phenolic compounds, terpenoids, and alkaloids. Although, flavonoids and phenolic compounds are well-known for their high antioxidant activities and associated with several pharmaceutical and medicinal applications reflected by its anti-cancer effect, cardioprotective effects, immune system promoting, and anti-inflammatory effects [52]; however, the correlation between the chemicals constituents and their bioactivity are not always positive. In recent years, plant-based polyphenols and flavonoids are used as the substitute for the many artificial antioxidants. It is evident that natural antioxidants are safer to use compared to artificial antioxidant, which is suspected to have adverse health effects $[53,54]$. Among six medicinal plants extract analyzed, $B$. pacumbis and $M$. koenigii have shown the highest TPC and TFC, whereas $A$. racemosus have shown the least amount. In order to further evaluate the biological activities of these extracts, we next investigated the antioxidant, anticancer, and anti-inflammatory activities.

Furthermore, chemotherapy is widely used for the treatment of cancer; its long-term exposure has several other health complications. Hence, scientists are trying to identify alternative treatment with fewer side effects. It is evident that the secondary metabolites from plants such as

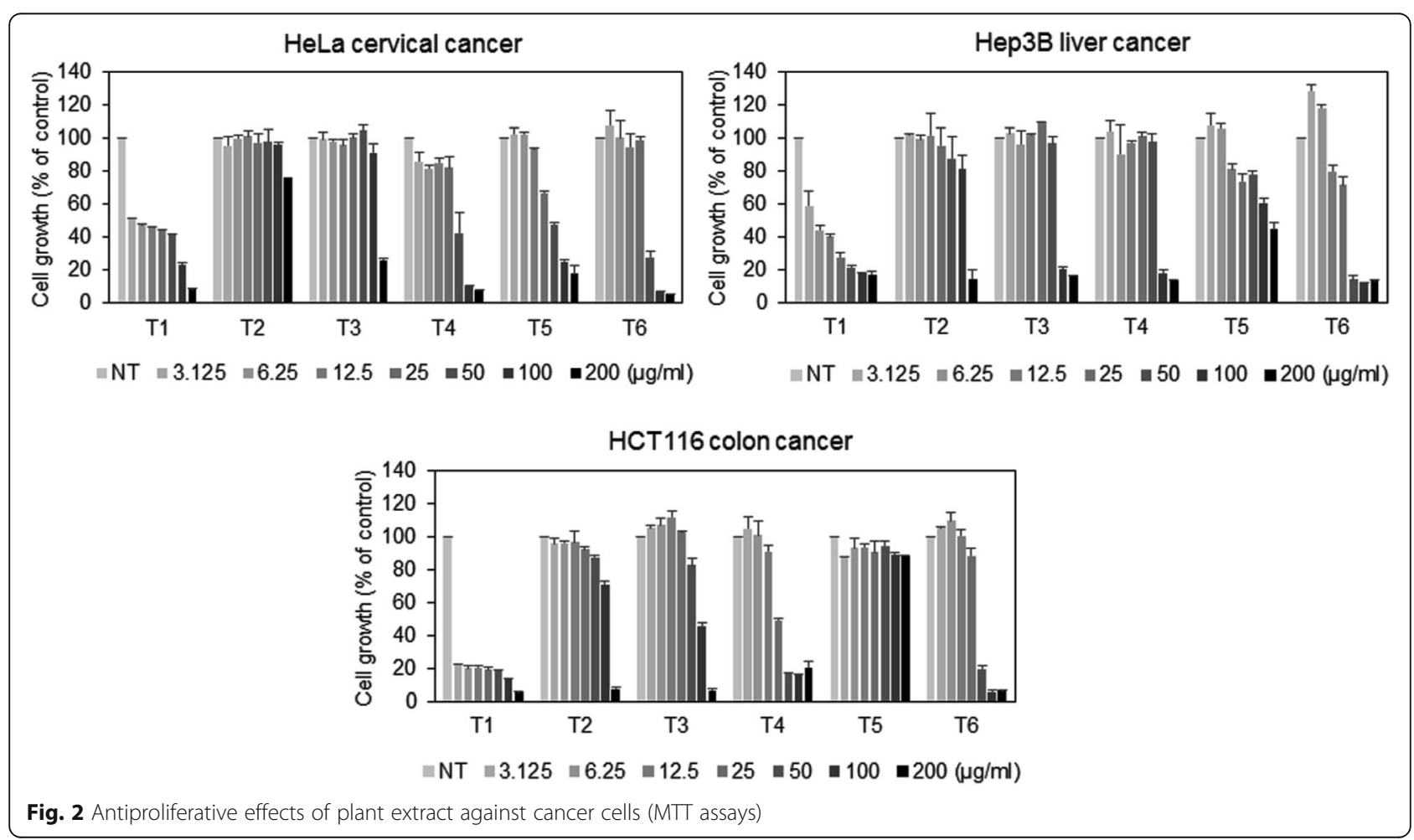




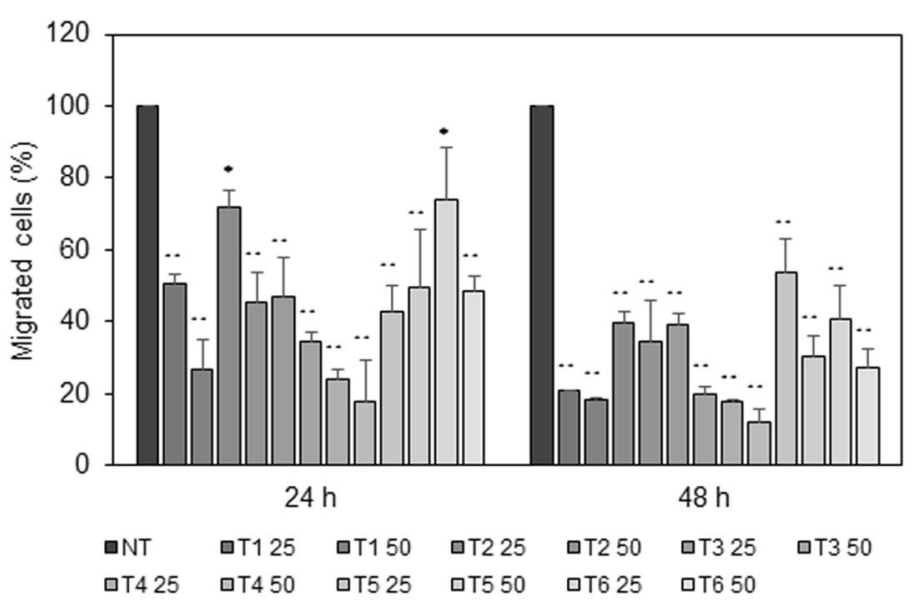

(A)

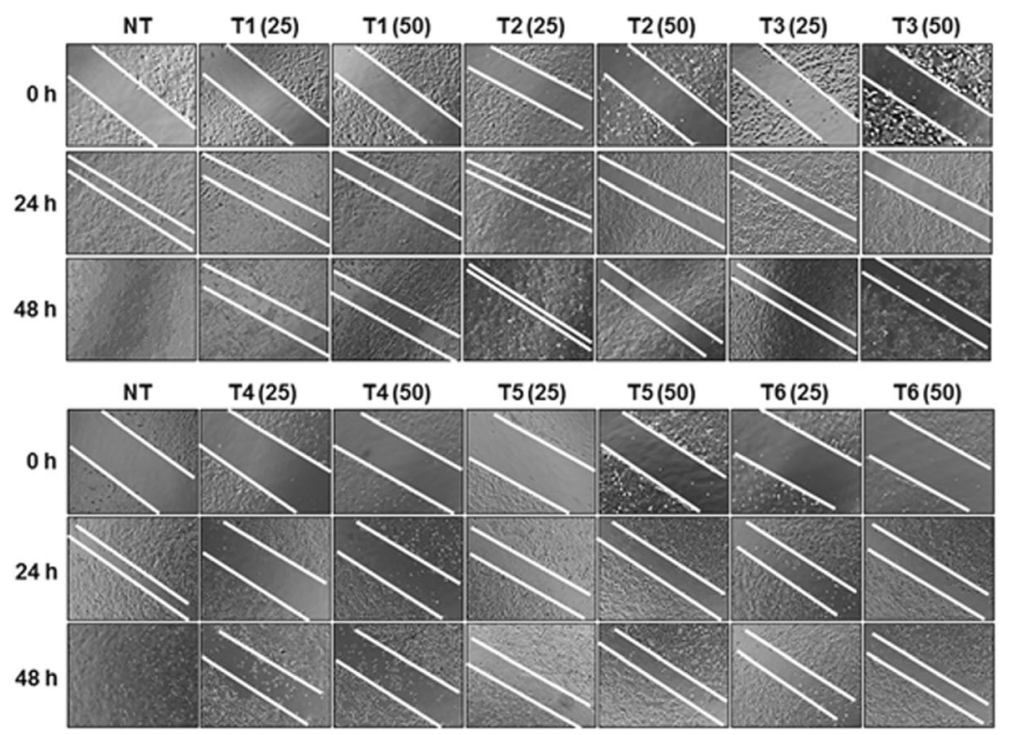

(B)

Fig. 3 Antimetastatic effects of plant extract against Hep3B cells $(\mathbf{a}, \mathbf{b})$. Statistical analysis was carried out using one-way ANOVA followed by $t$ test. ${ }^{*}$ Statistically significant between cell lines treatment with extract at ${ }^{*} p<0.05,{ }^{* *} p<0.001$ vs. the control

terpenoids, phenolics, and alkaloids have a broad spectrum of bioactivities including anticancer properties [55]. However, their use in clinical practice is not possible due to their toxicity and imperfect bioavailability. Thus, modification of the chemical structure of secondary metabolites from plants is one strategic way to increase their anticancer action and decrease their toxicity and side effects $[56,57]$. Hence, continuous screening of the medicinal herbs and plants for its potential anticancer activities is of growing scientific interest. Our analysis revealed the anti-cancer potential of $M$. azedarach, P. benthamii, $B$. pacumbis, and M. koenigii extracts against HeLa, Hep3B, and HCT116 cell lines among six analyzed plant extract. However, A. racemosus and T. linearis showed relatively lower inhibitory activities against the analyzed cancer cell lines and also found toxic to the normal cell.
Although studies on anticancer potential of different fractions and pure isolates of $M$. azedarach, A. racemosus, $T$. linearis, and $M$. koenigii have been already carried out in different cell lines, no detail investigations were carried out for these plant extracts against examined cancer cell lines. This is the first report on anticancer and anti-inflammatory activities of $P$. benthamii and $B$. pacumbis. Previous studies on $M$. azedarach extract against human urinary bladder carcinoma cells and human breast cancer cells possess no significant inhibition $[58,59]$. However, some steroids isolated from M. azedarach showed good anticancer potential with low cytotoxicity against human lung cancer cell lines and the human glioma cancer cell line [60]. The essential oil from $T$. linearis showed prominent anti-proliferative activity against human breast cancer MCF-7, hormone- 

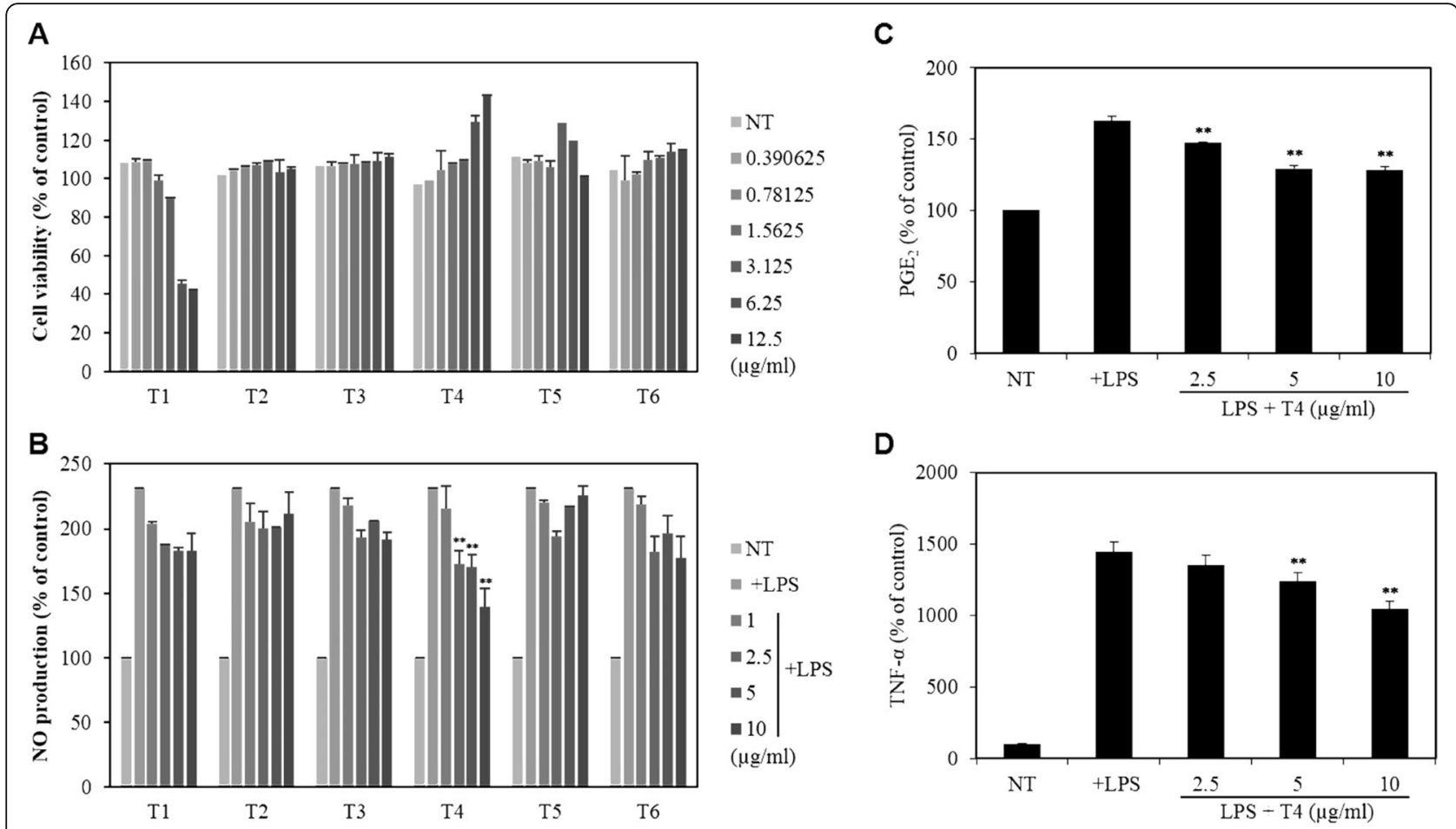

Fig. 4 Effect of plant extract on viability of RAW264.7 macrophage cells $(\mathbf{a}, \mathbf{b})$ and anti-inflammatory effect of T4 in LPS-stimulated RAW264.7 macrophage cells $(\mathbf{c}, \mathbf{d})$. Statistical analysis was carried out using one-way ANOVA followed by t-test. *Statistically significant between cell lines treatment with extract at ${ }^{* *} p<0.001$ vs. LPS-treated control

dependent prostate carcinoma, and fibroblast cell lines [61]. Our result on T. linearis is comparable with the previous work on antiproliferative effects on the HCT-116 cell line [62]. In particular, Thymol is a marker compound of Genus Thymus and possesses the great anticancer activities on different cell lines but possesses cytotoxicity against HeLa cell in a concentration-dependent manner [63, 64] and intestinal cells line [65]. Similarly, Shatavarin IV from $A$. racemosus possesses significant anticancer activity against human breast cancer, human colon adenocarcinoma, and human kidney carcinoma cell lines [66]; silver nanoparticles from $A$. racemosus shows cytotoxicity effect against ovarian cancer cell line [67]; and crude root extract shows cytotoxicity against lung cancer cells [68]. A preliminary screening of leaf extracts of $M$. koenigii exhibited significant anticarcinogenic effects on inhibiting the growth of breast cancer cell line [69] and girinimbine (a carbazole alkaloid) isolated from $M$. koenigii shows good antiproliferative effects against lung cancer cells [70]. Moreover, M. koenigii leaf extract possesses a dosedependent decrease in cell viability/proliferation of human colon, prostate, liver, and cervical cancer cell lines [71]. Although numerous researches showed potential anticancer properties of these plant extracts, the activity based on pure isolates must be done for the authentication and scrutiny of absolute anticancer potential and feasibility of drug formulation from the plant extracts.
The plant-based medicine induces wound healing and regeneration of the lost tissue by multiple mechanisms which are also considered cheap, affordable, and safe. However, scientific validation, standardization, and safety evaluation of plants used in traditional medicine should be carried out before we recommend those plant materials for further application [72].. This is the first report on the wound healing capacity of $P$. benthamii and $B$. pacumbis. Our study revealed the wound healing activity of $P$. benthamii and B. pacumbis methanol extract and has great tendencies to suppress the migration of Hep3B cells. It is also less toxic compared to the other plant extract examined. Our finding opens up the possibilities in the future to identify the potential anticancer compounds in P. benthamii and B. pacumbis. Flavonoids and phenolics are among the most potent ingredients that underlie the protective effect of diets rich in fruits, vegetables, and plants with respect to minimize the risk of causing cancer [73, 74]. Hence, flavonoid compounds could probably be responsible for the anticancer activity of the plant extracts [69]. However, more research should be carried out for the understanding of the correlation between flavonoids and anticancer activities of plant extracts.

Inflammation is a physiological response to tissue injury, which is triggered by the physical, toxic chemical, and microbial agents. The inflammatory process involves 
acute and chronic. The nitric oxide (NO) is a wellknown pro-inflammatory mediator associated with much physiological process. Hence, the NO production was used as tools for the measurement of the inflammation; reduction of NO production has been characterized as an effective strategy for the treatment of inflammationrelated diseases. Furthermore, transcription factors such as NF- $\mathrm{kB}$ are responsible for the expression of the proinflammatory mediators during the process of inflammation. The NF-kB pathway is triggered by proinflammatory stimuli such as IL-1 and TNF- $\alpha$. The primary mediators of acute inflammation include histamine, serotonin, and COX-2, whereas chronic is mediated by $\mathrm{PGE}_{2}, \mathrm{NO}$, and lipoxygenases [75]. It is reported that chronic inflammation might lead to ailments such as peptic ulcer, rheumatoid arthritis, and cancer as well [76]. Our result revealed that among six medicinal plants extract evaluated, $P$. benthamii showed potential anti-inflammatory activities with no toxicity against the RAW264.7 murine macrophage cells. Our results revealed that analyzed plant extracts have cytotoxicity and wound healing results; we analyzed only $P$. benthamii for anti-inflammatory properties because of its less toxicity and good activity. There are several examples of other plant species having anti-inflammatory properties. Taking into the account $\beta$-carboline alkaloids, C- 1 and $\mathrm{C}-2$, isolated from $M$. azedarach have a potential therapeutic effect on inhibiting NO production [77], the treatment of murine macrophages with $A$. racemosus significantly inhibited OTA-induced suppression of chemotactic activity and production of TNF- $\alpha$ [78], Girinimbine from $M$. koenigii inhibits the release of $\mathrm{NO}$ in RAW 264.7 cells [79], and different Thymus species [80-82] and Bergenia species [83] have already known anti-inflammatory properties.

\section{Conclusion}

Among the six selected plant species evaluated for its potential biological activities, $M$. azedarach revealed the good anti-cancer. However, $P$. benthamii shows remarkable wound healing and anti-inflammatory activities with no toxicity. Although, other plant species possess antiproliferative activity, the toxicity was high for the consideration of anticancer therapeutic. Our result opens up the possibility in the future to identify the potential therapeutic agents from $P$. benthamii for the development of herbal-based medicine.

\section{Abbreviations}

ABTS: 2,2'-Azino-bis (3-ethylbenzothiazoline-6-sulfonic acid) diammonium salt; DMEM: Dulbecco's modified eagle medium; DPPH: 2,2-Diphenyl-1picrylhydrazyl; FBS: Fetal bovine serum; GAE: Gallic acid equivalent; HCT116: Colon carcinoma; HeLa: Cervical carcinoma; Hep3B: Hepatocarcinoma; KCLB: Korean Cell Line Bank; LPS: Lipopolysaccharide; MTT: 3-(4,5-Dimethylthiazol-2-yl)-2,5- diphenyltetrazolium bromide; QUE: Quercetin equivalent; TFC: Total flavonoid content; TPC: Total phenolic content

\section{Acknowledgements}

We would like to thank Sun Moon University, South Korea for providing facilities for anticancer and anti-inflammatory activities analysis and we would also like to thank National Herbarium and Plant Laboratory (KATH), Godhawori, Lalitpur Nepal and Prof. Dr. Ram Prasad Chaudhary for the plant identification and authorization.

\section{Study involving plants}

The plant species were scientifically authorized in the National Herbarium and Plant Laboratories, Department of plant resources, Ministry of forest and soil conservation, Government of Nepal with reference (Ref No. 2074/075-230).

\section{Authors' contributions}

BPP conceptualized the work. KA and SPP perform the photochemical analysis. TPC, TFC, and antioxidant measurements. BPP, HJS, EKL, and HJJ perform the anti-cancer and anti-inflammatory activities analysis and data interpretation. SPP, BPP, and HJS wrote, edited, and revised the manuscripts. All authors have read and approved the final manuscript.

\section{Funding}

Funded by H-Plant Pvt. Ltd. through the grant support (2012-2017) from Korea International Cooperation Agency (KOICA) and partial support through grant support from NRF Basic Science Research Program (NRF-

2016R1D1A1B03932956) and NRF grant funded by the Ministry of Science and ICT (NRF-2019R1A2C1009033).

Availability of data and materials

Data will be available by corresponding authors upon reasonable request.

Ethics approval and consent to participate

Not applicable.

\section{Consent for publication}

Not applicable.

\section{Competing interests}

Authors declare no any conflict of interest.

\section{Author details}

'Department of Chemical Science and Engineering, Kathmandu University, P.O. Box 6250, Kavre, Dhulikhel, Nepal. ${ }^{2}$ Department of Pharmaceutical Engineering \& Biotechnology, Sun Moon University, 70 Sunmoon-ro 221, Tangjeong-myeon, Asan-si, Chungnam 31460, Korea. ${ }^{3}$ Genome-Based BiolT Convergence Institute, Asan, Korea.

Received: 26 November 2019 Accepted: 7 September 2020 Published online: 29 October 2020

References

1. Van der Merwe D, Swan G, Botha C (2001) Use of ethnoveterinary medicinal plants in cattle by Setswana-speaking people in the Madikwe area of the north West Province of South Africa. J S Afr Vet Assoc 72:189-196 https:// doi.org/https://doi.org/10.4102/jsava.v72i4.651

2. Rokaya MB, Münzbergová Z, Timsina B (2010) Ethnobotanical study of medicinal plants from the Humla district of western Nepal. J Ethnopharmacol 130:485-504 https://doi.org/https://doi.org/10.1016/j.jep. 2010.05.036

3. Kumar VP, Chauhan NS, Padh H, Rajani M (2006) Search for antibacterial and antifungal agents from selected Indian medicinal plants. J Ethnopharmacol 107:182-188 https://doi.org/https://doi.org/10.1016/j.jep.2006.03.013

4. Mothana RA, Abdo SA, Hasson S, Althawab F, Alaghbari SA, Lindequist U (2010) Antimicrobial, antioxidant and cytotoxic activities and phytochemical screening of some yemeni medicinal plants. Evidence-Based Complementary Altern Med 7:323-330 https://doi.org/https://doi.org/10. 1093/ecam/nen004

5. Ouerghemmi I, Rebey IB, Rahali FZ, Bourgou S, Pistelli L, Ksouri R, Marzouk B, Tounsi MS (2017) Antioxidant and antimicrobial phenolic compounds from extracts of cultivated and wild-grown Tunisian Ruta chalepensis. J Food 
Drug Anal 25:350-359 https://doi.org/https://doi.org/10.1016/j.fda.2016.04. 001

6. Zilani MNH, Sultana T, Rahman SA, Anisuzzman M, Islam MA, Shilpi JA, Hossain MG (2017) Chemical composition and pharmacological activities of Pisum sativum. BMC Complementary Altern Med 17:1-9 https://doi.org/ https://doi.org/10.1186/s12906-017-1699-y

7. Pisoschi AM, Pop A (2015) The role of antioxidants in the chemistry of oxidative stress: a review. Eur J Med Chem 97:55-74 https://doi.org/https:// doi.org/10.1016/j.ejmech.2015.04.040

8. Friedman M (2007) Overview of antibacterial, antitoxin, antiviral, and antifungal activities of tea flavonoids and teas. Mol Nutr Food Res 51:116134 https://doi.org/https://doi.org/10.1002/mnfr.200600173

9. Cushnie TT, Lamb AJ (2011) Recent advances in understanding the antibacterial properties of flavonoids. Int J Antimicrob Agents 38:99-107 https://doi.org/https://doi.org/10.1016/j.jiantimicag.2011.02.014

10. Akindele AJ, Wani Z, Mahajan G, Sharma S, Aigbe FR, Satti N, Adeyemi OO, Mondhe DM (2015) Anticancer activity of Aristolochia ringens Vahl. (Aristolochiaceae). J Tradit Complementary Med 5:35-41 https://doi.org/ https://doi.org/10.1016/j.jtcme.2014.05.001

11. Khali N, Ashour M, Singab AN, Salama O (2018) Bioassay guided fractionation and cytotoxic activity of Daucus carota var. boissieri. Future J Pharm Sci 4:14-17 https://doi.org/https://doi.org/10.1016/j.jps.2017.07.002

12. Chanda S, Nagani K (2013) In vitro and in vivo methods for anticancer activity evaluation and some Indian medicinal plants possessing anticancer properties: an overview. J Pharmacogn Phytochem 2:140-152

13. Silva C, Correia-Branco A, Andrade N, Ferreira AC, Soares ML, Sonveaux P, Stephenne J, Martel F (2019) Selective pro-apoptotic and antimigratory effects of polyphenol complex catechin: lysine 1:2 in breast, pancreatic and colorectal cancer cell lines. Eur J Pharmacol 859:172533 https://doi.org/ https://doi.org/10.1016/j.ejphar.2019.172533

14. Divisi D, Di Tommaso S, Salvemini S, Garramone M, Crisci R (2006) Diet and cancer. Acta Biomed Ateneo Parmense 77:118

15. Rahman MM, Khan MA (2013) Anti-cancer potential of south Asian plants. Nat Prod Bioprospect 3:74-88 https://doi.org/https://doi.org/10.1007/s13659013-0027-6

16. Gautam N, Mantha AK, Mittal S (2014) essential oils and their constituents as anticancer agents: a mechanistic view. Biomed Res Int 2014 https://doi.org/ https://doi.org/10.1155/2014/154106

17. Solowey E, Lichtenstein M, Sallon S, Paavilainen H, Solowey E, LorberboumGalski H (2014) evaluating medicinal plants for anticancer activity. Sci World J 2014 https://doi.org/https://doi.org/10.1155/2014/721402

18. Russo M, Spagnuolo C, Tedesco I, Russo GL (2010) Phytochemicals in cancer prevention and therapy: truth or dare? Toxins 2:517-551 https://doi.org/ https://doi.org/10.3390/toxins2040517

19. Vauzour D, Rodriguez-Mateos A, Corona G, Oruna-Concha MJ, Spencer JP (2010) Polyphenols and human health: prevention of disease and mechanisms of action. Nutrients 2:1106-1131 https://doi.org/https://doi.org/ 10.3390/nu2111106

20. Hmidani A, Bouhlali EDT, Khouya T, Ramchoun M, Filali-Zegzouti Y, Alem C, Benlyas M (2019) Antioxidant, anti-inflammatory and anticoagulant activities of three Thymus species grown in southeastern Morocco. Future J Pharm Sci 5:4 https://doi.org/https://doi.org/10.1186/s43094-019-0005-x

21. Cappell MS, Schein JR (2000) Diagnosis and treatment of nonsteroidal antiinflammatory drug-associated upper gastrointestinal toxicity. Gastroenterol Clin N Am 29:97-124 https://doi.org/https://doi.org/10.1016/S08898553(05)70109-6

22. Chiffelle I, Huerta Fuentes A, Lizana Rojas D (2009) Physical and chemical characterization of Melia azedarach L. fruit and leaf for use as botanical insecticide. Chil J Agric Res 69:38-45. https://doi.org/10.4067/S071858392009000100005

23. Qureshi H, Arshad M, Akram A, Raja NI, Fatima S, Amjad MS (2016) Ethnopharmacological and phytochemical account of paradise tree (Melia azedarach L.: meliaceae). Pure and Appl Biol 5:5-14. https://doi.org/10. 19045/bspab.2016.50002

24. Kunwar RM, Nepal BK, Kshhetri HB, Rai SK, Bussmann RW (2006) Ethnomedicine in Himalaya: a case study from Dolpa, Humla, Jumla and mustang districts of Nepal. J Ethnobiol Ethnomed 2:27 https://doi.org/ https://doi.org/10.1186/1746-4269-2-27

25. Alok S, Jain SK, Verma A, Kumar M, Mahor A, Sabharwal M (2013) Plant profile, phytochemistry and pharmacology of Asparagus racemosus
(Shatavari): a review. Asian Pac J Trop Dis 3:242-251 https://doi.org/https:// doi.org/10.1016/S2222-1808(13)60049-3

26. Rajbhandari M, Mentel R, Jha P, Chaudhary R, Bhattarai S, Gewali MB, Karmacharya N, Hipper M, Lindequist U (2009) Antiviral activity of some plants used in Nepalese traditional medicine. Evidence-Based Complementary Altern Med 6:517-522 https://doi.org/https://doi.org/10, 1093/ecam/nem156

27. Akhtar MS, Jabeen Q, Khan HU, Maheen S, Karim S, Rasool S, Malik MN, Khan K, Mushtaq MN, Latif F, Tabassum N (2014) Pharmacological evaluation of antihypertensive effect of aerial parts of Thymus linearis benth. Acta Pol Pharm 71:677-682

28. Qadir MI, Parveen A, Abbas K, Ali M (2016) Analgesic, anti-inflammatory and anti-pyretic activities of Thymus linearis. Pak J Pharm Sci 29:591-594

29. Ahmad T, Alamgeer A, Nawaz M, Mushtaq MN, Batool A (2014) Hepatoprotective activity of Thymus linearis against paracetamol-and carbon tetrachloride-induced hepatotoxicity in albino mice. Bangladesh J Pharmacol 9:230-234 https://doi.org/https://doi.org/10.3329/bjp.v9i2.18329

30. Parveen A, Kyunn W (2016) Antioxidant and anti-cholinergic activities of phenolic compounds isolated from Thymus linearis collected from dir, Pakistan. Vegetos 29:41-46. https://doi.org/10.5958/2229-4473.2016.00009.4

31. Naz A, Saeed M, Hussain MM, Ishaq MS (2015) In vitro phytochemical and antimicrobial screening of Thymus linearis. Bangladesh J Pharmacol 10:21-26 http://doi.org/https://doi.org/10.3329/bjp.v10i1.20639

32. Kasote DM, Jagtap SD, Thapa D, Khyade MS, Russell WR (2017) Herbal remedies for urinary stones used in India and China: a review. J Ethnopharmacol 203:55-68 https://doi.org/https://doi.org/10.1016/j.jep.2017. 03.038

33. Raj AJ, Biswakarma S, Pala NA, Shukla G, Kumar M, Chakravarty S, Bussmann RW (2018) Indigenous uses of ethnomedicinal plants among forestdependent communities of northern Bengal, India. J Ethnobiol Ethnomed 14:8 https://doi.org/https://doi.org/10.1186/s13002-018-0208-9

34. Balakrishnan R, Vijayraja D, Jo S-H, Ganesan P, Su-Kim I, Choi DK (2020) Medicinal profile, phytochemistry, and pharmacological activities of Murraya koenigii and its primary bioactive compounds. Antioxidants 9:101 https:// doi.org/https://doi.org/10.3390/antiox9020101

35. Kunwar RM, Uprety Y, Burlakoti C, Chowdhary C, Bussmann RW (2009) Indigenous use and ethnopharmacology of medicinal plants in far-West Nepal. Ethnobot Res Appl 7:005-028

36. Patwardhan B, Warude D, Pushpangadan P, Bhatt N (2005) Ayurveda and traditional Chinese medicine: a comparative overview. Evidence-Based Complementary Altern Med 2:465-473 https://doi.org/https://doi.org/10. 1093/ecam/neh140

37. Upreti A, Byanju B, Fuyal M, Chhetri A, Pandey P (2018) Evaluation of aamylase, lipase inhibition and in-vivo pharmacological activities of Eucalyptus camaladulensis Dehnh leaf extract. J Trad Complementary Med 30:1e7 https://doi.org/https://doi.org/10.1016/j.jtcme.2018.07.001

38. Kim D-O, Jeong SW, Lee CY (2003) Antioxidant capacity of phenolic phytochemicals from various cultivars of plums. Food Chem 81:321-326 https://doi.org/https://doi.org/10.1016/S0308-8146(02)00423-5

39. Edeoga HO, Okwu D, Mbaebie B (2005) Phytochemical constituents of some Nigerian medicinal plants. Afr J Biotechnol 4:685-688 https://doi.org/https:// doi.org/10.5897/AJB2005.000-3127

40. Abdullahi M, Ilyas N, Ibrahim H (2013) Evaluation of phytochemical screening and analgesic activity of aqueous extract of the leaves of Microtrichia perotitii dc (Asteraceae) in mice using hotplate method. Med Plant Res 3:37-43 https://doi.org/https://doi.org/10.5376/mpr.2013.03.0005

41. Baba SA, Malik SA (2015) Determination of total phenolic and flavonoid content, antimicrobial and antioxidant activity of a root extract of Arisaema jacquemontii Blume. J Taibah Univ Sci 9:449-454 https://doi.org/https://doi. org/10.1016/j.jtusci.2014.11.001

42. Thapa R, Upreti A, Pandey BP (2017) Evaluation of biological activities and chemical constituent of storage medicinal plant materials used as a traditional medicine in Nepal. J Int Ethnopharm 6:369-377 https://doi.org/ https://doi.org/10.5455/jice.20171029093516

43. Munro B, Vuong QV, Chalmers AC, Goldsmith CD, Bowyer MC, Scarlett CJ (2015) Phytochemical, antioxidant and anti-cancer properties of Euphorbia tirucalli methanolic and aqueous extracts. Antioxidants 4:647-661 https://doi. org/https://doi.org/10.3390/antiox4040647

44. Liyanaarachchi GD, Samarasekera JKRR, Mahanama KRR, Hemalal KDP (2018) Tyrosinase, elastase, hyaluronidase, inhibitory and antioxidant activity of $\mathrm{Sri}$ 
Lankan medicinal plants for novel cosmeceuticals. Ind Crop Prod 111:597605 https://doi.org/https://doi.org/10.1016/j.indcrop.2017.11.019

45. Rehana D, Mahendiran D, Kumar RS, Rahiman AK (2017) Evaluation of antioxidant and anticancer activity of copper oxide nanoparticles synthesized using medicinally important plant extracts. Biomed Pharmacother 89:1067-1077 https://doi.org/https://doi.org/10.1016/j.biopha. 2017.02.101

46. Jonkman JE, Cathcart JA, Xu F, Bartolini ME, Amon JE, Stevens KM, Colarusso $P$ (2014) An introduction to the wound healing assay using live-cell microscopy. Cell Adhes Migr 8:440-451 https://doi.org/https://doi.org/10. 4161/cam.36224

47. Han JM, Lee EK, Gong SY, Sohng JK, Kang YJ, Jung HJ (2019) Sparassis crispa exerts anti-inflammatory activity via suppression of TLR-mediated NF-KB and MAPK signaling pathways in LPS-induced RAW264. 7 macrophage cells. J Ethnopharmacol 231:10-18 https://doi.org/https://doi.org/10.1016/j.jep.2018. 11.003

48. Esposito D, Munafo Jr JP, Lucibello T, Baldeon M, Komarnytsky S, Gianfagna TJ (2013) Steroidal glycosides from the bulbs of Easter lily (Lilium longiflorum Thunb.) promote dermal fibroblast migration in vitro. J Ethnopharmacol 148:433-440 https://doi.org/https://doi.org/10.1016/j.jep.2013.04.032

49. Tsai M-L, Lin C-C, Lin W-C, Yang C-H (2011) Antimicrobial, antioxidant, and anti-inflammatory activities of essential oils from five selected herbs. Biosci Biotechnol Biochem 75:1977. https://doi.org/https://doi.org/10.1271/bbb. 110377

50. Zimmermann-Klemd AM, Konradi V, Steinborn C, Ücker A, Falanga CM, Woelfle U, Huber R, Jürgenliemk G, Rajbhandari M, Gründemann C (2019) Influence of traditionally used Nepalese plants on wound healing and immunological properties using primary human cells in vitro. J Ethnopharmacol 235:415-423 https://doi.org/https://doi.org/10.1016/j.jep. 2019.02.034

51. Abdelkhalek AA, Sharaf A-MM, Rabie M, El-Subbagh HI (2017) Derivatives of Cucurbitacin-E-glucoside produced by Curvularia lunata NRRL 2178: antiinflammatory, antipyretic, antitumor activities, and effect on biochemical parameters. Future J Pharm Sci 3:124-130 https://doi.org/https://doi.org/10. 1016/j.jps.2017.04.006

52. Anacleto SL, Lajolo FM, Hassimotto NM (2019) Estimation of dietary flavonoid intake of the Brazilian population: a comparison between the USDA and phenol-explorer databases. J Food Compos Anal 78:1-8 https:// doi.org/https://doi.org/10.1016/j.jfca.2019.01.015

53. Jiao Y, Quek SY, Gu M, Guo Y, Liu Y (2020) Polyphenols from thinned young kiwifruit as natural antioxidant: protective effects on beef oxidation, physicochemical and sensory properties during storage. Food Control 108: 106870 https://doi.org/https://doi.org/10.1016/j.foodcont.2019.106870

54. Singh P, Grewal AS, Pandita D, Lather V (2018) Synthesis and evaluation of a series of caffeic acid derivatives as anticancer agents. Future J Pharm Sci 4: 124-130 https://doi.org/https://doi.org/10.1016/j.fjps.2017.11.002

55. Seca AM, Pinto DC (2018) Plant secondary metabolites as anticancer agents: successes in clinical trials and therapeutic application. Int J Mol Sci 19:263 https://doi.org/https://doi.org/10.3390/ijms19010263

56. Guo Z (2017) The modification of natural products for medical use. Acta Pharm Sin B 7:119-136 https://doi.org/https://doi.org/10.1016/j.apsb.2016.06. 003

57. Yao H, Liu J, Xu S, Zhu Z, Xu J (2017) The structural modification of natural products for novel drug discovery. Expert Opin Drug Discovery 12:121-140 https://doi.org/https://doi.org/10.1080/17460441.2016.1272757

58. Mothana RA, Kriegisch S, Harms M, Wende K, Lindequist U (2011) Assessment of selected Yemeni medicinal plants for their in vitro antimicrobial, anticancer, and antioxidant activities. Pharm Biol 49:200-210 https://doi.org/https://doi.org/10.3109/13880209.2010.512295

59. Malar TJ, Antonyswamy J, Vijayaraghavan P, Kim YO, Al-Ghamdi AA, Elshikh MS, Hatamleh AA, Al-Dosary MA, Na SW, Kim HJ (2020) In-vitro phytochemical and pharmacological bio-efficacy studies on Azadirachta indica a. Juss and Melia azedarach Linn for anticancer activity. Saudi J Biol Sci 27:682-688 https://doi.org/https://doi.org/10.1016/j.sjbs.2019.11.024

60. Wu S-B, Ji Y-P, Zhu J-J, Zhao Y, Xia G, Hu YH, Hu JF (2009) Steroids from the leaves of Chinese Melia azedarach and their cytotoxic effects on human cancer cell lines. Steroids 74:761-765 https://doi.org/https://doi.org/10.1016/ j.steroids.2009.04.005

61. Hussain Al, Anwar F, Chatha SA, Latif S, Sherazi ST, Ahmad A, Worthington J, Sarker SD (2013) Chemical composition and bioactivity studies of the essential oils from two Thymus species from the Pakistani flora. LWT Food
Sci Technol 50:185-192 https://doi.org/https://doi.org/10.1016/j.lwt.2012.06. 003

62. Bashir R, Ovais Zargar QP, Hamid R (2019) In vitro antiproliferative activity of Thymus linearis essential oil from five ecozones of Kashmir valley. Pharm Innov J 8:205-210

63. Abed RM (2011) Cytotoxic, cytogenetics and immunomodulatory effects of thymol from Thymus vulgaris on cancer and normal cell lines in vitro and in vivo. Al-Mustansiriyah J Sci 22:41-53

64. Meeran N, Fizur M, Javed H, Al Taee H, Azimullah S, Ojha SK (2017) Pharmacological properties and molecular mechanisms of thymol: prospects for its therapeutic potential and pharmaceutical development. Front Pharmacol 8:380 https://doi.org/https://doi.org/10.3389/fphar.2017. 00380

65. Llana-Ruiz-Cabello M, Gutiérrez-Praena D, Pichardo S, Moreno FJ, Bermúdez JM, Aucejo S, Cameán AM (2014) Cytotoxicity and morphological effects induced by carvacrol and thymol on the human cell line Caco-2. Food Chem Toxicol 64:281-290 https://doi.org/https://doi.org/10.1016/j.fct.2013.12. 005

66. Mitra SK, Prakash NS, Sundaram R (2012) Shatavarins (containing Shatavarin IV) with anticancer activity from the roots of Asparagus racemosus. Indian J Pharmacol 44:732-736 https://dx.doi.org/https://doi.org/10.4103/0253-7613. 103273

67. Khanra K, Panja S, Choudhuri I, Chakraborty A, Bhattacharyya N (2016) Bactericidal and cytotoxic properties of silver nanoparticle synthesized from root extract of Asparagus racemosus. Nano Biomed Eng 8:39-46 https://dx. doi.org/https://doi.org/10.5101/nbe.v8i1.p39-46

68. Biswas D, Mathur M, Bhargava S, Malhotra H (2018) Anticancer activity of root extracts in nonsmall cell lung cancer Asparagus racemosus A549 cells. Asian J Pharm Pharmacol 4:764-770 https://doi.org/https://doi.org/10.31024/ ajpp.2018.4.6.7

69. Ghasemzadeh A, Jaafar HZ, Rahmat A, Devarajan T (2014) Evaluation of bioactive compounds, pharmaceutical quality, and anticancer activity of curry leaf (Murraya koenigii L.). evidence based complementary Altern med 2014 https://doi.org/https://doi.org/10.1155/2014/873803

70. Mohan S, Abdelwahab SI, Cheah S-C, Sukari MA, Syam S, Shamsuddin N, Rais Mustafa M (2013) apoptosis effect of girinimbine isolated from Murraya koenigii on lung cancer cells in vitro. Evidence Based Complementary Altern Med 2013 https://doi.org/https://doi.org/10.1155/2013/689865

71. Noolu B, Ismail A (2015) Anti-proliferative and proteasome inhibitory activity of Murraya koenigii leaf extract in human cancer cell lines. Phytomedicine 2: 1-9. https://doi.org/10.15562/phytomedicine.2015.18

72. Raina R, Prawez S, Verma P, Pankaj N (2008) Medicinal plants and their role in wound healing. Vet Scan 3:1-7

73. Ghasemzadeh A, Jaafar HZ (2011) Antioxidant potential and anticancer activity of young ginger (Zingiber officinale roscoe) grown under different CO2 concentration. J Med Plants Res 5:3247-3255

74. Medina-Holguín AL, Holguín FO, Micheletto S, Goehle S, Simon JA, O'Connell MA (2008) Chemotypic variation of essential oils in the medicinal plant, Anemopsis californica. Phytochemistry 69:919-927 https:/doi.org/ https://doi.org/10.1016/j.phytochem.2007.11.006

75. Abdulkhaleq L, Assi M, Abdullah R, Zamri-Saad M, Taufiq-Yap YH, Hezmee MN (2018) The crucial roles of inflammatory mediators in inflammation: a review. Vet World 11:627-635 https://dx.doi.org/https://doi.org/10.14202/ vetworld.2018.627-635

76. Coussens LM, Werb Z (2002) Inflammation and cancer. Nature 420:860-867 https://doi.org/https://doi.org/10.1038/nature01322

77. Lee BG, Kim SH, Zee OP, Lee KR, Lee HY, Han JW, Lee HW (2000) Suppression of inducible nitric oxide synthase expression in RAW 264.7 macrophages by two $\beta$-carboline alkaloids extracted from Melia azedarach. Eur J Pharmacol 406:301-309 https://doi.org/https://doi.org/10.1016/S00142999(00)00680-4

78. Dhuley J (1997) Effect of some Indian herbs on macrophage functions in ochratoxin a treated mice. J Ethnopharmacol 58:15-20 https://doi.org/ https://doi.org/10.1016/S0378-8741(97)00072-X

79. Iman V, Mohan S, Abdelwahab SI, Karimian H, Nordin N, Fadaeinasab M, Noordin MI, Noor SM (2017) Anticancer and anti-inflammatory activities of girinimbine isolated from Murraya koenigii. Drug Des Dev Ther 11:103-121 https://dx.doi.org/https://doi.org/10.2147/DDDT.S115135

80. Zuzarte M, Alves-Silva JM, Alves M, Cavaleiro C, Salgueiro L, Cruz MT (2018) New insights on the anti-inflammatory potential and safety profile of Thymus carnosus and Thymus camphoratus essential oils and their main 
compounds. J Ethnopharmacol 225:10-17 https://doi.org/https://doi.org/10. 1016/j.jep.2018.06.025

81. Habashy NH, Serie MMA, Attia WE, Abdelgaleil SA (2018) Chemical characterization, antioxidant and anti-inflammatory properties of Greek Thymus vulgaris extracts and their possible synergism with Egyptian Chlorella vulgaris. J Funct Foods 40:317-328 https://doi.org/https://doi.org/ 10.1016/j.jf.2017.11.022

82. Rodrigues V, Cabral C, Evora L, Ferreira I, Cavaleiro C, Cruz MT, Salqueiro L (2019) Chemical composition, anti-inflammatory activity and cytotoxicity of Thymus zygis L. subsp. sylvestris (Hoffmanns. \& link) Cout. Essential oil and its main compounds. Arab J Chem 12:3236-3243 https://doi.org/https://doi. org/10.1016/j.arabjc.2015.08.026

83. Khan MY (2016) Phytopharmacological and chemical profile of Bergenia ciliata. Int J Phytopharm 6:90-98. https://doi.org/10.7439/ijpp

\section{Publisher's Note}

Springer Nature remains neutral with regard to jurisdictional claims in published maps and institutional affiliations.

\section{Submit your manuscript to a SpringerOpen ${ }^{\circ}$ journal and benefit from:}

- Convenient online submission

- Rigorous peer review

- Open access: articles freely available online

- High visibility within the field

- Retaining the copyright to your article

Submit your next manuscript at $\boldsymbol{\nabla}$ springeropen.com 